\title{
(nie)Wiedza nauczycieli mieszkających na pograniczu polsko-czeskim o swoich sąsiadach
}

Streszczenie: Położenie geograficzne może być czynnikiem sprzyjającym nawiązywaniu bliższych międzysąsiedzkich relacji. Dzisiaj liczne granice - tak jak właśnie polsko-czeska - mają charakter „zdematerializowany” i istnieją w pamięci i świadomości ludzi. Czy jednak rzeczywiście bliskie sąsiedztwo, podobne uwarunkowania społeczne i kulturowe a nawet bliskość językowa powoduje, że poszukujemy wiedzy o swoich sąsiadach? W naszym kraju od kilku lat możemy obserwować swoiste zafascynowanie Czechami. To wszystko ma swój wymiar ogólnopolski. Czy jednak sytuacja na pograniczu, a więc w bezpośrednim sąsiedztwie, jest podobna? W realizowanych przeze mnie badaniach wśród nauczycieli mieszkających na pograniczu polsko-czeskim interesowało mnie, jak respondenci oceniają swoją wiedzę o Czechach i jak opisują swoich sąsiadów.

Słowa kluczowe: nauczyciel, sąsiedzi, pogranicze polsko-czeskie, wiedza

Położenie geograficzne może być czynnikiem sprzyjającym nawiązywaniu bliższych międzysąsiedzkich relacji. Dzisiaj liczne granice - tak jak polsko-czeska mają charakter „zdematerializowany” i istnieją w pamięci i świadomości ludzi. Czy jednak rzeczywiście bliskie sąsiedztwo, podobne uwarunkowania społeczne i kulturowe, a nawet bliskość językowa powodują, że poszukujemy wiedzy o swoich sąsiadach? W naszym kraju od kilku lat możemy obserwować swoiste zafascynowanie Czechami. Nie jest to tylko związane z wyjazdami do takich uczęszczanych i rozpoznawalnych miast jak Praga czy cieszące się ogromnym zainteresowaniem Skalne Miasto położone tuż przy naszej południowej granicy $^{1}$. Czesi cieszą się największą sympatią Polaków wśród innych narodów również w badaniach realizowanych od lat przez CBOS. Wprawdzie deklarowana sympatia waha się nieznacznie - 51\% badanych w roku 2011 (Stosunek Polaków do... nr 13/2011), trzy lata później odnotowany został minimalny spa-

1 Jest to widoczne również w sytuacji poszukiwania atrakcyjnych miejsc wypoczynku, co przyjmuje chwilami formę masową, na którą gospodarze nie są przygotowani, por.: Skalne miasto oblegane przez Polaków... 
dek do 50\% (Stosunek Polaków do innych... nr 20/2014), po kolejnych trzech latach rekordowy wzrost do 59\% (Stosunek do innych... nr 21/2017) i chociaż rok 2018 przyniósł ogólne zmniejszenie sympatii Polaków do innych narodów, w dalszym ciągu to właśnie Czesi są tymi najbardziej lubianymi z 44\% deklarowanej sympatii (Stosunek do innych... nr 37/2018). Dużą popularnością cieszą się w Polsce również klasycy literatury czeskiej i publikacje popularyzujące wiedzę o Czechach wydawane przez takich autorów jak Aleksander Kaczorowski (2007, 2012, 2018) czy Mariusz Szczygieł (2006, 2010, 2012). Nieoficjalny ruch czechofilów znajduje swoich zwolenników na portalach społecznościowych (Jestem Czechofilem...) ${ }^{2}$ czy na licznych blogach (Czechyokiem Czechofila; Czechofil; Český sen). Bardziej sformalizowane działania prowadzą powołane stowarzyszenia, w których zrzeszeni są pasjonaci kultury, sztuki i codziennego życia czeskiego. To wszystko ma swój wymiar ogólnopolski. Czy jednak sytuacja na pograniczu, a więc w bezpośrednim sąsiedztwie, jest podobna? W realizowanych przeze mnie badaniach wśród nauczycieli mieszkających na pograniczu polsko-czeskim interesowało mnie, jak respondenci oceniają swoją wiedzę o Czechach i jak opisują swoich sąsiadów. Przygotowany tekst podzieliłam na cztery części. W pierwszej z nich prezentuję specyfikę pogranicza polsko-czeskiego, dalej opisuję założenia metodologiczne badań własnych, a następnie prezentuję opisy i wyjaśnienia uzyskanych wyników badań. Całość kończą konkluzje.

\section{Pogranicze - przestrzeń budowania nowej tożsamości?}

Pogranicze jest to terytorium usytuowane między dwoma obszarami państwowymi (lub regionalnymi), które cechuje przemieszczanie o charakterze etnicznym lub narodowym będące efektem usytuowania w bliskości przestrzennej (Kłoskowska, 1996, s. 125). Jest to zatem zarówno obszar fizyczny, która jest efektem wyznaczenia w określonej przestrzeni granicy między państwami czy narodami, jak i przestrzeń społeczna, którą charakteryzuje silne zróżnicowanie kulturowe - świata materialnego, jak i niematerialnego. Owo zróżnicowanie dotyczy takich sfer, jak język, religia, tradycja, świadomość przynależności narodowej, pamięć historyczna, ale również sposób przestrzennego zagospodarowania pogranicza i jego specyficznej architektury (Śliż, Szczepański, 2016, s. 49). Pogranicze to obszar zagęszczenia różnych granic - zarówno politycznych, jak i historycznych, etnicznych, społeczno-

2 Na dzień 25 maja 2018 roku strona miała 7295 polubień. 
-kulturowych, które są elementem tożsamości mieszkańców, a mieszkanie na pograniczu jest związane ze świadomością istnienia owych granic i koniecznością ich przekraczania (Sadowski, 2008, s. 20).

Śląsk Cieszyński jest przykładem pogranicza zmieniającego swój charakter w zależności od realizowanej centralnie polityki międzynarodowej państwa. Jeszcze na początku lat 30. XX wieku stosunki między Polską i Czechosłowacją były poprawne, a Śląsk Cieszyński uchodził za miejsce tolerancji i wzajemnej akceptacji. Druga połowa lat 30. przyniosła zmianę w stosunkach międzynarodowych, co zaostrzyło krytyczne stanowisko polskiej mniejszości wobec różnorodnych niesprawiedliwości i krzywd, i następnie przerodziło się w manifestację antypaństwowej postawy (Gawrecká i Gwarecki 2007, s. 34). Również okres po II wojnie światowej był pełen napięcia we wzajemnych relacjach, a fizyczna granica była trudna do przekroczenia dla mieszkańców z obu jej stron. Współcześnie granice bardzo często straciły dawne znaczenie i nie pełnią przypisywanych im przez wieki funkcji. Przystąpienie do Wspólnoty Europejskiej w 2004 roku przyczyniło się również do zmian na terenie pogranicza polsko-czeskiego. To najdłuższe dla Polski pogranicze (liczące 796 kilometrów) jest bardzo zróżnicowane pod względem społeczno-kulturowym i ekonomicznym. Polsko-czeskie pogranicze stało się modelowym przykładem najbardziej innowacyjnej współpracy transgranicznej. Tutaj powstawały pierwsze w Polsce euroregiony, a następnie Europejskie Ugrupowanie Współpracy Terytorialnej (Skorupska, 2014). Jest to pochodną intensywnego oddziaływania obu stron w wymiarze kulturowym, społecznym, ekonomicznym i politycznym. Ta nowa sytuacja - wzmocniona jeszcze porozumieniem Schengen (Polska weszła do układu Schengen 21 grudnia 2007 roku) - sprzyja przenikaniu się i budowaniu nowej jakości funkcjonowania na pograniczu dla jego mieszkańców. Sama w sobie przestrzeń pogranicza sprzyja stykaniu i przenikaniu się kultur, a także nawiązywaniu i utrzymywaniu kontaktów międzykulturowych. Kształtuje się specyficzna tożsamość pogranicza, która jednak nie sprowadza się tylko do prostej sumy wynikającej z historii, języków, tradycji czy kultury, ale jest to „wynik wzajemnego przenikania się wzbogacania poszczególnych komponentów tożsamości. Wytworzenie takiej tożsamości zapobiega narastaniu tendencji nacjonalistycznych i ksenofobicznych, a przyczynia się do wzrostu szacunku i zrozumienia dla innych narodów kultur i cywilizacji” (Trzcielińska-Polus, 2007, s. 44). Tak więc pogranicze to zarówno teren możliwej pokojowej koegzystencji wielu kultur, ale z drugiej zarzewie potencjalnego konfliktu, którego podłożem jest zróżnicowanie aksjologiczne i normatywne. 
Pograniczność, zdaniem Andrzeja Sadowskiego, oznacza szczególnie zjawiska (procesu) masowego i trwałego przepływu (przenikania) przez granice międzykulturowe ludzi, ich wzorów kulturowych, wartości, w połączeniu $\mathrm{z}$ aktywnymi działaniami na rzecz podtrzymania lub rozwoju tych kontaktów przez sąsiednie zbiorowości, ich instytucje oraz poszczególnych mieszkańców (2008, s. 23). Czy jednak sam fakt mieszkania w strefie pogranicza zachęca mieszkańców do aktywności w tym zakresie? Osoby badane to nauczyciele - z założenia powinno to wskazywać na ich aktywność, chęć poznawania Innego, poszukiwanie wiedzy, co powinno być - w sytuacji pracy w środowisku zróżnicowanym kulturowo - czymś oczywistym.

\section{Założenia metodologiczne badań własnych}

Badania zrealizowane zostały na terenie pogranicza polsko-czeskiego (w powiecie cieszyńskim), a wybór miejsca miał charakter celowy. Moje dotychczasowe doświadczenia z realizowania projektów transgranicznych wskazywały na duże zainteresowanie nauczycieli pracujących w Polsce Czechami i Republiką Czeską. To zainteresowanie nauczycieli, ich zaangażowanie w proponowane działania oraz opinie na temat korzyści ze wspólnej pracy nauczycieli z obu stron granicy stało się inspiracją do przeprowadzenia badań wśród szerszej grupy nauczycieli. Chciałam sprawdzić, czy poglądy reprezentowane przez nauczycieli zaangażowanych w projekty są zbliżone do tych podzielanych przez szerszą, reprezentatywną grupę osób pracujących w szkołach.

Łącznie na badanym terenie zostało rozdanych 600 kwestionariuszy ankiet, a ostatecznej analizie poddano 118 (część kwestionariuszy odrzucono ze względu na niekompletne dane, dużo kwestionariuszy nie zostało zwróconych). Badana grupa jest reprezentatywna, a wyniki przeprowadzonych badań poddano analizie ilościowej ${ }^{3}$. W opracowaniu uzyskanych danych empirycznych zastosowane zostały metody statystyczne: testowanie statystycznej istotności różnic między zmiennymi - za pomocą testu Chi - kwadrat $\left(\chi^{2}\right)$, a do zmierzenia siły związku między zmiennymi użyto współczynnika $V$ Cramera $(0 \leq V \leq 1)$. Zastosowano program do analizy statystycznej zawarty w komputerowym pakiecie STATISTICA 10PL (Lauszniewicz, Słaby, 2008).

3 Badania były realizowane na potrzebę szerszych analiz, ale te prezentowane w artykule nie zostały tam zawarte. Pozostałe wyniki zostały opublikowane w: Lewowicki, T., Szczurek-Boruta, A. i Szafrańska, A. 2017. 
W grupie osób badanych dominowały kobiety $(87,4 \%)$. Najliczniejsza grupa osób była w wieku powyżej 40 lat $(49,1 \%)$, mniej liczna to nauczyciele z przedziału 31-40 lat (24,6\%), a najmniej liczna to najmłodsi - w wieku 20-30 lat (8,8\%). Respondenci to grupa zróżnicowana ze względu na staż pracy: 0-10 lat - 19,3\%, 11-20 lat - 33,3\% powyżej 20 lat - 35,1\%. Większość badanych osób mieszka na wsi - 54,4\%, w mieście $29,8 \%$.

Interesowało mnie, jak badani nauczyciele opisują swoich sąsiadów, z czym - grupie osób mieszkających na pograniczu - kojarzą się Czesi i Czechy, a także jak oceniają własną wiedzę z zakresu między innymi kultury, sztuki, tradycji czy kulinariów czeskich.

\section{Pod svícnem bývá nejvêtší tma - najciemniej bywa pod latarnią...}

Pytałam badanych nauczycieli, jakie są ich skojarzenia z Czechami. Najliczniej wskazywane były te związane z kulinariami, przede wszystkim z knedlikami (31 wskazań). Kolejna grupa skojarzeń, którą określiłam jako pozytywne, najczęściej miała charakter opisowy (24 osoby). Nauczyciele pisali o pogodnym, uporządkowanym narodzie, życzliwych ludziach, społeczeństwie liberalnym w sposobie bycia i zachowania. Częste były również odniesienia do języka czeskiego - przedstawianego jako zabawny, śmieszny czy nawet dziecinny (17 deklaracji). Czeskie produkty (wśród nich dominowały wskazania na piwo) to również elementy kojarzące się z Czechami (15 odpowiedzi). Wśród podawanych odpowiedzi były również skojarzenia negatywne - zasygnalizowane przez 12 respondentów. Nauczyciele pisali o tym, że Czesi są jednolici, brakuje im własnego zdania i są konformistami (przede wszystkim w odniesieniu do polityki). Wskazywane były również braki w umiejętnościach prowadzenia samochodów. Najbardziej charakterystyczne elementy związane z czeską kulturą to przede wszystkim filmy i bajki. Kilka osób (6) podkreśliło, że ich pierwszym skojarzeniem z Czechami jest cieszyński targ, który przyciąga sąsiadów i jest przestrzenią, w której najłatwiej można ich spotkać. Charakterystyczny wygląd (szerzej opisywany przy prezentacji kolejnych wyników) jest również wskazywany przez kilku respondentów jako pierwsze skojarzenie z południowymi sąsiadami. Co ciekawe, dziesięć osób napisało, że nie ma żadnych skojarzeń z Czechami. Szczegółowe dane prezentuję na wykresie 1. 
Wykres 1. Deklarowane skojarzenia z Czechami

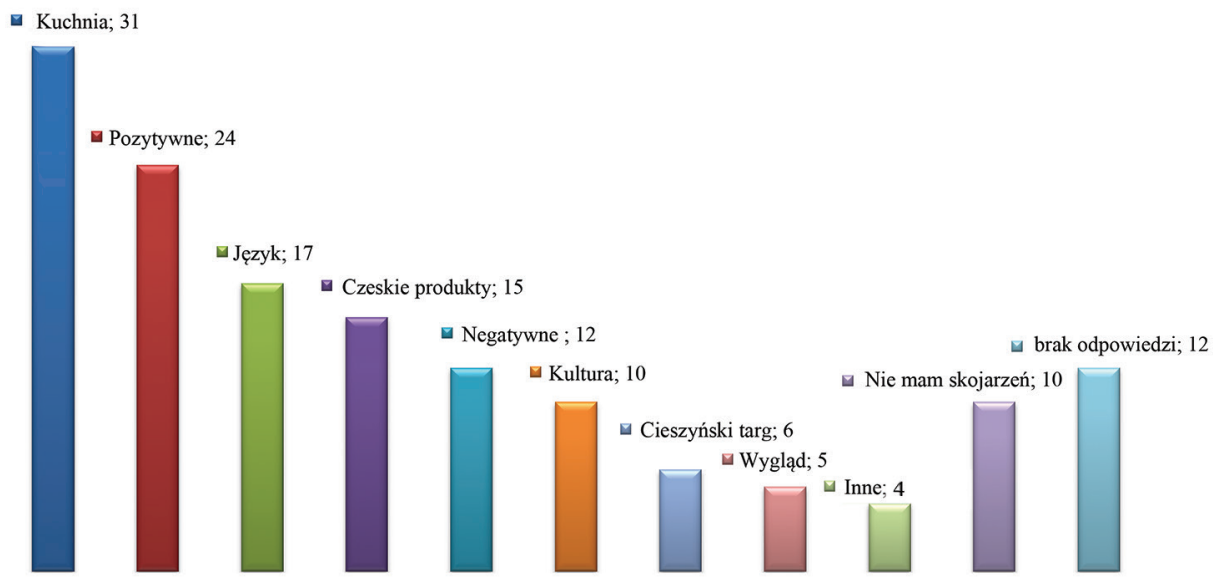

Źródło: badania własne.

Kolejne pytanie miało charakter pogłębienia poprzedniego, prosiłam bowiem badanych, by wskazali konkretne cechy charakteru, wyglądu osób narodowości czeskiej. Najliczniejsze wypowiedzi odnosiły się do wyglądu zewnętrznego. Najbardziej typowe dla Czechów, zdaniem respondentów, są długie włosy u mężczyzn: „Taka fryzura na Czecha - z przodu krótko, a z tyłu włosy do ramion". Rzadziej wskazywany był sposób ubierania się - zwłaszcza w stosunku do mężczyzn określany jako niezbyt trafny, poprzez zakładanie np. skarpet do sandałów. Z kolei atuty wyglądu naszych południowych sąsiadów są - zdaniem nauczycieli - pochodną uprawiania przez nich sportu. Kolejna wyróżniona kategoria łączy w sobie wskazania odnoszące się do pozytywnego podejścia Czechów do świata i ludzi. Natomiast w kategorii podejście do życia i spraw codziennych mamy nakreślony obraz ludzi bardzo racjonalnych, twardo stąpających po ziemi, czasem nadmiernie oszczędnych. Zwrócona została tu również uwaga na ostrożność „narodową” - zarówno w relacjach indywidualnych, jak i w stosunkach międzynarodowych. Nie wypowiedziało się na ten temat 18 nauczycieli, a 10 stwierdziło, że nie potrafi nic charakterystycznego wskazać. Szczegółowe dane w ujęciu \% prezentuję na wykresie 2. 
Wykres 2. Wskazywane przez nauczycieli cechy charakteru, wygladu typowe dla osób narodowości czeskiej

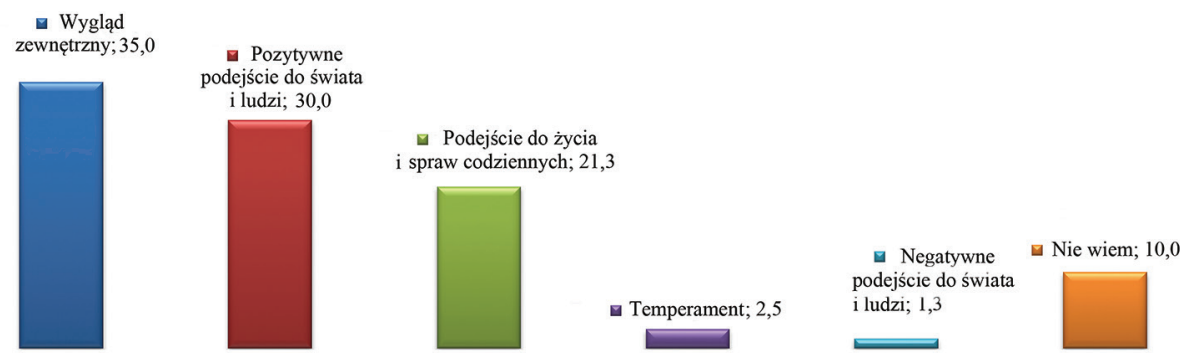

Źródło: badania własne N 100\%=100.

Pytałam badanych, jak częste są ich kontakty z osobami narodowości czeskiej. Nauczyciele mieli możliwość wyboru odpowiedzi od codziennych, poprzez częste, rzadkie do braku bezpośrednich kontaktów. Nikt z nauczycieli nie zaznaczył codziennych kontaktów, niemal co piąty $(22,4 \%)$ deklarował kontakt częsty lub brak kontaktu (20,7\%), a najliczniejsze wskazania zostały zaznaczone przy odpowiedzi „rzadko” (56,9\%).

Tabela 1. Deklarowane poszukiwanie wiedzy na temat Czechów i Republiki Czeskiej a częstotliwość kontaktów z osobami narodowości czeskiej

\begin{tabular}{|c|c|c|c|c|c|}
\hline \multirow{2}{*}{\multicolumn{3}{|c|}{$\begin{array}{l}\text { tak } \\
\text { nie }\end{array}$}} & \multicolumn{3}{|c|}{$\begin{array}{l}\text { Poszukiwanie wiedzy na temat } \\
\text { Czechów i Republiki Czeskiej }\end{array}$} \\
\hline & & & Ogółem & & \\
\hline \multirow{6}{*}{$\begin{array}{l}\text { Częstotliwość } \\
\text { kontaktów z osobami } \\
\text { narodowości czeskiej }\end{array}$} & \multirow{2}{*}{ częste } & Liczebność & 9 & 16 & 25 \\
\hline & & $\%$ & $36,0 \%$ & $64,0 \%$ & $100,0 \%$ \\
\hline & \multirow{2}{*}{ rzadkie } & Liczebność & 9 & 56 & 65 \\
\hline & & $\%$ & $13,8 \%$ & $86,2 \%$ & $100,0 \%$ \\
\hline & \multirow{2}{*}{$\begin{array}{l}\text { brak bezpośrednich } \\
\text { kontaktów }\end{array}$} & Liczebność & 2 & 21 & 23 \\
\hline & & $\%$ & $8,7 \%$ & $91,3 \%$ & $100,0 \%$ \\
\hline \multirow{2}{*}{\multicolumn{2}{|c|}{ Ogółem }} & Liczebność & 20 & 93 & 113 \\
\hline & & & $17,7 \%$ & $82,3 \%$ & $100,0 \%$ \\
\hline
\end{tabular}

$\mathrm{x}^{2}=7,691 \mathrm{df}=2$, dla $\mathrm{p}=0,021<0,05$

V Cramera $=0,261$

Interesowało mnie, czy deklarowana częstotliwość kontaktów z Czechami jest czynnikiem w sposób istotny warunkującym wiedzę badanych na temat sąsiadów. Respondenci najczęściej odpowiadali, że nie poszukują wiedzy na temat Czechów i Republiki Czeskiej. Stwierdzono słaby związek między 
częstotliwością kontaktów z osobami narodowości czeskiej a deklarowanym poszukiwaniem wiedzy o południowych sąsiadach, dla której $\mathrm{V}$ Cramera = 0,261 (szczegóły prezentuję w tabeli 1 ). Wiedzy nie poszukują Ci, którzy nie mają kontaktów z Czechami lub mają okazjonalny - rzadki.

Sprawdziłam również, czy i jak częstotliwość kontaktów z osobami narodowości czeskiej warunkuje sposób oceniania swojej wiedzy z zakresu kultury czeskiej. Stwierdzono umiarkowany związek, dla której V Cramera=0,323. Osoby deklarujące częste kontakty najczęściej wskazywały na dobrą znajomość kultury czeskiej, a osoby wskazujące na rzadkie kontakty oceniały najczęściej swoją wiedzę z tego zakresu jako dostateczną. Szczegółowe dane prezentuję w tabeli 2 .

Tabela 2. Deklarowana częstotliwość kontaktów z osobami narodowości czeskiej a samoocena wiedzy z zakresu kultury Czech

\begin{tabular}{|l|l|c|c|c|c|}
\hline \multirow{2}{*}{ Kategorie } & \multicolumn{2}{|c|}{$\begin{array}{c}\text { Częstotliwość kontaktów } \\
\text { z osobami narodowości czeskiej }\end{array}$} & \multirow{2}{*}{ Ogółem } \\
\cline { 2 - 5 } Znajomość kultury czeskiej & rzadkie & $\begin{array}{c}\text { brak bezpośrednich } \\
\text { kontaktów }\end{array}$ & \\
\hline \multirow{2}{*}{ bardzo dobra } & Liczebność & 1 & 0 & 0 & 1 \\
\cline { 2 - 6 } & $\%$ & $100,0 \%$ & $0,0 \%$ & $0,0 \%$ & $100,0 \%$ \\
\hline \multirow{2}{*}{ dobra } & Liczebność & 16 & 13 & 4 & 33 \\
\cline { 2 - 6 } & $\%$ & $48,5 \%$ & $39,4 \%$ & $12,1 \%$ & $100,0 \%$ \\
\hline \multirow{2}{*}{ dostateczna } & Liczebność & 7 & 39 & $20,7 \%$ & $100,0 \%$ \\
\hline \multirow{2}{*}{ brak znajomości } & $\%$ & $12,1 \%$ & $67,2 \%$ & 5 & 18 \\
\hline & Liczebność & 1 & 12 & $27,8 \%$ & $100,0 \%$ \\
\hline \multirow{2}{*}{ Ogółem } & Liczebność & 25 & $66,7 \%$ & 64 & 110 \\
\cline { 2 - 6 } & $\%$ & $22,7 \%$ & $58,2 \%$ & $19,1 \%$ & $100,0 \%$ \\
\hline
\end{tabular}

$\mathrm{X}^{2}=22,940 \mathrm{df}=6$, dla $\mathrm{p}=0,001<0,05$

V Cramera $=0,323$

Stwierdzono umiarkowany związek deklarowanej częstotliwości kontaktów z odpowiedziami dotyczącymi samooceny wiedzy nauczycieli z zakresu znajomości kuchni czeskiej, dla której V Cramera=0,309. Osoby deklarujące najczęściej bardzo dobrą znajomość kuchni czeskiej deklarowały częste kontakty z osobami narodowości czeskiej, z kolei deklarujący dobrą i dostateczną znajomość tego aspektu złożyły deklaracje o rzadkich kontaktach z osobami narodowości czeskiej. Szczegółowe dane prezentuję w tabeli 3. 
Tabela 3. Deklarowana częstotliwość kontaktów z osobami narodowości czeskiej a samoocena znajomości kuchni czeskiej

\begin{tabular}{|c|c|c|c|c|c|}
\hline \multirow{2}{*}{\multicolumn{2}{|c|}{ Znajomość kuchni czeskiej }} & \multicolumn{3}{|c|}{$\begin{array}{c}\text { Częstotliwość kontaktów } \\
\text { z osobami narodowości czeskiej }\end{array}$} & \multirow{3}{*}{$\begin{array}{c}\text { Ogółem } \\
8\end{array}$} \\
\hline & & \multirow{2}{*}{$\begin{array}{c}\text { rzadkie } \\
6\end{array}$} & \multirow{2}{*}{\begin{tabular}{|c|}
$\begin{array}{c}\text { brak bezpośrednich } \\
\text { kontaktów }\end{array}$ \\
1 \\
\end{tabular}} & \multirow[b]{2}{*}{1} & \\
\hline \multirow{2}{*}{ bardzo dobra } & Liczebność & & & & \\
\hline & $\%$ & $75,0 \%$ & $12,5 \%$ & $12,5 \%$ & $100,0 \%$ \\
\hline \multirow{2}{*}{ dobra } & Liczebność & 11 & 23 & 4 & 38 \\
\hline & $\%$ & $28,9 \%$ & $60,5 \%$ & $10,5 \%$ & $100,0 \%$ \\
\hline \multirow{2}{*}{ dostateczna } & Liczebność & 6 & 38 & 15 & 59 \\
\hline & $\%$ & $10,2 \%$ & $64,4 \%$ & $25,4 \%$ & $100,0 \%$ \\
\hline \multirow{2}{*}{ brak znajomości } & Liczebność & 2 & 3 & 2 & 7 \\
\hline & $\%$ & $28,6 \%$ & $42,9 \%$ & $28,6 \%$ & $100,0 \%$ \\
\hline \multirow{2}{*}{ Ogółem } & Liczebność & 25 & 65 & 22 & 112 \\
\hline & $\%$ & $22,3 \%$ & $58,0 \%$ & $19,6 \%$ & $100,0 \%$ \\
\hline
\end{tabular}

$\mathrm{X}^{2}=21,412 \mathrm{df}=6$, dla $\mathrm{p}=0,002<0,05$

V Cramera $=0,309$

Stwierdzono również umiarkowany związek deklarowanej częstotliwości kontaktów z odpowiedziami dotyczącymi samooceny wiedzy nauczycieli z zakresu znajomości języka czeskiego, dla którego V Cramera=0,355. Osoby deklarujące bardzo dobrą znajomość języka jednocześnie często się kontaktują z osobami narodowości czeskiej. Z kolei dobrą i dostateczną znajomość języka deklarują najczęściej osoby rzadko kontaktujące się z Czechami. Podobnie jest w grupie osób wskazujących na brak znajomości języka czeskiego - tu najczęściej badani wskazywali na rzadki lub na zupełny brak kontaktu. Szczegółowe dane prezentuję w tabeli 4.

Tabela 4. Deklarowana częstotliwość kontaktów z osobami narodowości czeskiej a samoocena wiedzy z zakresu języka czeskiego

\begin{tabular}{|l|l|c|c|c|c|}
\hline \multirow{2}{*}{ Kategorie } & \multicolumn{3}{|c|}{$\begin{array}{c}\text { Częstotliwość kontaktów } \\
\text { z osobami narodowości czeskiej }\end{array}$} & \multirow{2}{*}{ Ogółem } \\
\cline { 3 - 6 } Znajomość języka czeskiego & rzadkie & $\begin{array}{c}\text { brak bezpośrednich } \\
\text { kontaktów }\end{array}$ & \\
\hline \multirow{2}{*}{ bardzo dobra } & Liczebność & 2 & 0 & 0 & 2 \\
\cline { 2 - 6 } & $\%$ & $100,0 \%$ & $0,0 \%$ & $0,0 \%$ & $100,0 \%$ \\
\hline \multirow{2}{*}{ dobra } & Liczebność & 8 & 10 & 1 & 19 \\
\cline { 2 - 6 } & $\%$ & $42,1 \%$ & $52,6 \%$ & $5,3 \%$ & $100,0 \%$ \\
\hline \multirow{2}{*}{ dostateczna } & Liczebność & 14 & 26 & 6 & 46 \\
\cline { 2 - 6 } & $\%$ & $30,4 \%$ & $56,5 \%$ & $13,0 \%$ & $100,0 \%$ \\
\hline
\end{tabular}




\begin{tabular}{|l|l|c|c|c|c|}
\hline \multirow{2}{*}{ brak znajomości } & Liczebność & 1 & 29 & 16 & 46 \\
\cline { 2 - 6 } & $\%$ & $2,2 \%$ & $63,0 \%$ & $34,8 \%$ & $100,0 \%$ \\
\hline \multirow{2}{*}{ Ogółem } & Liczebność & 25 & 65 & 23 & 113 \\
\cline { 2 - 6 } & $\%$ & $22,1 \%$ & $57,5 \%$ & $20,4 \%$ & $100,0 \%$ \\
\hline
\end{tabular}

$\chi^{2}=28,550 \mathrm{df}=6$, dla $\mathrm{p}=0,00<0,05$

V Cramera $=0,355$

\section{Konkluzje}

Charakterystyczne dla pogranicza jest mieszkanie na tym samym obszarze dwóch lub więcej zbiorowości, wyposażonych w kultury o różnym stopniu odrębności, a mieszkańców pogranicza postrzegamy jako osoby reprezentujące zróżnicowane systemy aksjologiczne i normatywne, które na skutek kontaktów z innymi systemami ulegają mniej lub bardziej istotnym modyfikacjom (Śliż i Szczepański, 2016, s. 49). Pogranicze to przestrzeń, która ma różny charakter kulturowo-społeczny ze względu na uwarunkowania polityczno-administracyjne. Intensywność kontaktów jest bowiem regulowana prawnymi rozwiązaniami o charakterze międzynarodowym. Jednak sam fakt dzielenia wspólnej, podzielonej w różnym stopniu przestrzeni nie gwarantuje występowania tam trwałych kontaktów międzykulturowych. „Teoretycznie może to być kontinuum od braku kontaktów międzykulturowych, stanu separacji i segregacji etnicznej poprzez różne postacie kontaktów częściowych, selektywnych, do współdziałania zbiorowości opartego na różnych zasadach (dominacji i podporządkowania, współdziałania opartego na zasadach demokratycznych)" (Sadowski, 2008, s. 23).

Zdematerializowana granica nie jest już przeszkodą w poznawaniu sąsiednich państw, a mieszkanie w strefie pogranicza sprzyja niemal codziennym kontaktom z sąsiadami. Ze względu na zachodzące zmiany ekonomiczne Czesi są stałymi klientami w polskich sklepach, korzystają również z oferty kulturowej. Podobnie dzieje się po czeskiej stronie, gdzie Polacy również poszukują tańszych towarów i korzystają z usług - zwłaszcza lokali gastronomicznych. Ta naturalna już sytuacja sprawia, że zmienia się charakter pogranicza. O ile w pierwszym etapie po wprowadzeniu strefy Schengen przekraczanie granicy miało charakter okazjonalny, dziś stało się codziennością. Tworzone wspólne ścieżki rowerowe, trasy spacerowe czy działania mające na celu poznawanie kultury, sztuki i tradycji ponad granicami to jedne z efektów współpracy transgranicznej, która z wymiaru instytucjonalnego zmieniła swój charakter również na indywidualny. Jest to widoczne w przestrzeni na 
przykład Cieszyna, ale jak wskazują uzyskane wyniki badań, nie jest to zjawisko powszechne wśród badanych nauczycieli. W opisywanej grupie dominowały osoby, które nigdy nie brały udziału w projektach transgranicznych, deklarowały, że nie poszukują wiedzy o swoich sąsiadach. Taki brak zainteresowania bliskim sąsiadem nie jest korzystnym zjawiskiem - zwłaszcza ze względu na oczekiwania stawiane przed nauczycielami, którzy powinni być dla swoich uczniów przewodnikami po świecie zróżnicowanym kulturowo.

\section{Bibliografia}

Gawrecká, M. i Gwarecki, D. 2007. Česko-polské vztahy ve Slezsku z historické perspektivy. W: Berlińska, D. i Korzeniowski, M. red. Tożsamość lokalna, regionalna, transgraniczna na pograniczu polsko-czeskim. Opole: PIN-Instytut Śląsk, ss. 28-37.

Jestem Czechofilem Pobrane z: https://www.facebook.com/czechofile/ (28.05.2018).

Kaczorowski, A. 2007. Praskie łowy. Warszawa: Świat Książki.

Kaczorowski, A. 2012. Praski elementarz. Wołowiec: Wydawnictwo Czarne. Kaczorowski, A. 2018. Ota Pavel. Pod powierzchnia. Wołowiec: Wydawnictwo Czarne.

Lewowicki, T., Szczurek-Boruta, A. i Szafrańska, A. 2017. Sfery życia duchowego dzieci, młodzieży i dorostych - studium z pogranicza polsko-czeskiego. O nauczycielach, ich spostrzeganiu świata społecznego i aktywności. T. 4. Cieszyn - Toruń: Wydział Etnologii i Nauk o Edukacji Uniwersytetu Śląskiego, Wydawnictwo Adam Marszałek.

Sadowski, A. 2008. Pogranicze - pograniczność - tożsamość pograniczna. Pogranicze. Studia Społeczne. XIV, ss. 17-30.

Skalne miasto oblegane przez Polaków... Pobrane z: http://natemat.pl/237 239 ,skalne-miasto-polacy-oblegaja-czeska-policja-zamyka-przejsciegraniczne (28.05.2018)

Skorupska, A. 2014. Współpraca samorządowa na pograniczu polsko-czeskim. Policy Paper, nr 17. Pobrane z: file://C:/Users/Admin/Desktop/ Naukowa\%20Praca\%202018/Teksty\%20do\%20Pogranicza/PISM\%20Policy\%20Paper\%20nr\%2017\%20(100)\%20PL.pdf

Stosunek do innych narodów. Komunikat z badań CBOS nr 21/2017 Pobrane z: https://www.cbos.pl/SPISKOM.POL/2017/K_021_17.PDF (28.05.2018) 
Stosunek do innych narodów. Komunikat z badań CBOS nr 37/2018 Pobrane z: https://www.cbos.pl/SPISKOM.POL/2018/K_037_18.PDF (28.05.2018). Stosunek Polaków do innych narodów. Komunikat z badań CBOS 20/2014

Pobrane z: https://www.cbos.pl/SPISKOM.POL/2014/K_020_14.PDF (28.05.2018).

Stosunek Polaków do innych narodów. Komunikat z badań CBOS BS. 13/2011

Pobrane z: https://www.cbos.pl/SPISKOM.POL/2011/K_013_11.PDF (28.05.2018).

Szczygieł, M. 2006. Gottland. Wołowiec: Wydawnictwo Czarne. Szczygieł, M. 2010. Zrób sobie raj. Wołowiec: Wydawnictwo Czarne.

Szczygieł, M. 2012. Láska nebeská. Warszawa: Wydawnictwo Agora S.A. Śliż, A. i Szczepański, M. 2016. Pogranicze polsko-czeskie w perspektywie socjologicznej. Kontekst kulturowy. Pogranicze. Studia Społeczne. XXVII, ss. 47-59.

Trzcielińska-Polus, A. 2007. Pogranicze polsko-czeskie. Uwarunkowania współpracy społeczności przygranicznych. W: Berlińska, D. i Korzeniowski, M. red. Tożsamość lokalna, regionalna, transgraniczna na pograniczu polsko-czeskim. Opole: PIN - Instytut Śląski, ss. 38-45.

\section{(Lack of) Knowledge concerning the neighbours presented by teachers living in the Polish-Czech borderland}

Abstract: Geographical location might be an enhancer of establishing close relations between neighbours. Today, many borders - as in the case of the PolishCzech one - are "dematerialized" and, in human consciousness, exist onlyin memory. However, do the close neighbourhood, similar social or cultural determinants and the closeness of languages really make people seek knowledge about their neighbours? What can be observed in Poland for several years is a real fascination with Czechs. This takes place in the overall national dimension. Yet, is the situation on the borderland (in the direct neighbourhood) similar? The studies conducted among teachers living in the Polish-Czech borderland are to answer how the respondents evaluate their knowledge concerning Czechs and how they describe their neighbours.

Keywords: teacher, neighbours, Polish-Czech borderland, knowledge 